\title{
Somatic genomic rearrangements in human leucocyte antigens region in solid ovarian tumors
}

\author{
N. V. Hryshchenko ${ }^{1}$, V. V. Gordiyuk ${ }^{1}$, S. A. Kravchenko ${ }^{1}$, \\ S. B. Arbuzova 2 , V. I. Kashuba ${ }^{1,3}$ \\ ${ }^{1}$ Institute of Molecular Biology and Genetics, NAS of Ukraine \\ 150, Akademika Zabolotnoho Str., Kyiv, Ukraine, 03143 \\ 2 Municipal Nonprofit Enterprise East-Ukrainian Specialized Center Of Medical Genetics and Prenatal Diagnosis \\ 35 Nakhimov av., Mariupol, Ukraine, 87517 \\ ${ }^{3}$ Karolinska Institutet \\ Stockholm SE-171 77, Sweden \\ nata.hr13e@gmail.com
}

The success of immunotherapy for ovarian cancer is determined by the effectiveness of the patient's immune response, as well as the qualitative and quantitative representation of antigens of the main histocompatibility complex in tumor cells and microenvironment. The level of the HLA (Human Leukocyte Antigens) genes expression in tumor tissue does not always correctly reflect the expression of these genes in different populations of tumor cells. Aim. To analyze the frequency and range of somatic deletions and duplications in the HLA locus. Methods. LOH-analysis (Loss of Heterozyhosity) of the STR-markers (Short Tandem Repeats) in the ovarian tumors of affected patients. Results. We have shown that complex somatic genomic reorganizations, involving several HLA loci, are quite common in ovarian tumors. The detected genetic alterations vary by both the type (deletions and mutations in STR alleles) and proportion of the sub-population of cells with the alterations. Conclusion. The results obtained allow us to propose the LOH-analysis for highly effective detection of aneuploidy and different types of somatic genomic reorganizations in the HLA region even in minor cell populations. This analysis provides the additional prognostic information for predicting the effectiveness of different types of ovarian cancer immunotherapy at the individual level.

Ke y w or d s: ovarian cancer, immune response, STR-marker, HLA, genetic alteration.

\section{Introduction}

In recent decades, great progress has been achieved in the treatment of such a serious disease as cancer. Thanks to the development of new treatment concepts, it had become pos-

(C) 2021 N. V. Hryshchenko et al.; Published by the Institute of Molecular Biology and Genetics, NAS of Ukraine on behalf of Biopolymers and Cell. This is an Open Access article distributed under the terms of the Creative Commons Attribution License (http://creativecommons.org/licenses/by/4.0/), which permits unrestricted reuse, distribution, and reproduction in any medium, provided the original work is properly cited 
sible to significantly reduce lethality, and increase the duration and quality of life of cancer patients. Nevertheless, ovarian cancer (OC) is still a life-threatening disease, being the 3rd most common and the most lethal of the gynecological cancers. According to the International Agency for Research on Cancer more than 200 thousand new cases of OC are registered worldwide each year resulting in over 100 thousand deaths per year in women. Thus, OC remains one of the most resistant to treatment among gynecological cancers. In 2017, the most significant achievement in gynecological oncology was considered to be the development of new approaches to treatment, the main of which for OC were the PARP (poly ADP ribose polymerase) inhibitors and immunotherapy [1]. It is proved that tumor elimination can be supported by an effective immune response. The cancer immuno-genomics is based on the principle that genomic alterations generate the potential cancer cells that produce "non-self" novel cell surface peptides recognized by the patient's Human Leukocyte Antigens (HLA) molecules. So specific T cell and $\mathrm{B}$ cell immunity might be stimulated by these antigens.

Currently, the great improvement in cancer treatment has been achieved by the development of the DNA based vaccine immunotherapy, both targeted and non-targeted (immuno-stimulants/adjuvants). The basis of most oncological immune vaccines is the induction of tumor antigen-specific cytotoxic CD8+ T cells [2-5]. Another approach leads to the activation of $\mathrm{CD} 4+\mathrm{T}$ cells although these cells play a major role in initiating and maintaining CD8+ T cells [6]. DNA vaccines have demonstrated the efficacy in prostate, cutaneous melanoma, lung and other types of cancer [7-10]. The main advantages of non-targeted immunotherapy are (i) universality for the majority of heterogenic cancer cells, (ii) low resistance to therapy, (iii) simplicity for transportation to the target; and (iv) low-cost production. However, the effectiveness of this type of immunotherapy depends on the patient's immune response and the HLA binding potential of micro-environment cells to detect somatic alterations in the cancer genome and their ability to produce the immune stimulatory agents. With the development of cancer immunotherapy, it became necessary to evaluate its effectiveness for a particular patient, because in addition to the advantages described above, such therapy has a number of side effects due to nonspecific autoimmune reaction. It has been shown that the alterations in the HLA class I and II antigen expression often have a negative impact on the progression of tumors growth, early disease recurrence and on the response to $\mathrm{T}$ cell-based immunotherapy in prostate and other cancer types [11, 12].

The HLA chromosomal region consists of several gene clusters on $6 \mathrm{p} 21.3$ and encodes cell surface molecules of human Major Histocompatibility Complex (MHC). MHC peptides are designed to present exogenous antigens to the T-cell receptor on $\mathrm{T}$ cells. The HLA genes are organized into 3 chromosome regions according to the functions of expressed antigens (class I-III). The major function of the HLA-antigens is to induce and regulate the immune responses. The lymphocytes that express CD8 are engaged with the HLA class I antigens to activate the cytotoxic function. So these HLA proteins should provide the capacity to effectively recognize alien agents, both 
exogenous pathogens and endogenous cancer cells. The class II HLA molecule is a heterodimer consisting of alfa and beta chains expressed on the surface of professional antigen presenting cells and of some cancer cells [13, 14]. It has been shown that the cancer cells with the HLA class II expression are effectively recognized by the patient's CD4+ T cells [15]. The dysregulation of the HLA class II pathway by tumors is associated with the avoidance of an immune response [16]. The HLA class III genes encode inflammation molecules; they express the complement factor B, cell signaling cytokine TNF-alpha, allograft inflammatory factor 1 and some other membrane proteins. It is known that an increased rate of somatic rearrangements in the HLA region is one of the possible mechanisms of the HLA antigens impaired expression resulting in an immune evasion in the development and progression of some types of cancers. On the other hand, the novel data on a single-cell level have demonstrated a huge heterogeneity of gene expression in multiple cell types of a tumor [17-19]. Hence, the estimation of the average expression levels in the tumor tissue is not a fully reliable indicator and does not reflect the population of tumor cells.

The aim of our study is to analyze the frequency and range of somatic deletions and duplications in the HLA locus using LOHanalysis (Loss of Heterozyhosity) of the STRmarkers (Short Tandem Repeats) in the ovarian tumors of affected patients. The detection of abnormalities in different HLA genes would suggest an imbalance in the expression of the corresponding antigens in the populations of tumor cells, which will allow us to predict the effectiveness of different types of the ovarian cancer immunotherapy at an individual level.

\section{Patients and Methods}

\section{Patients}

We used a previously presented patients group created in collaboration with the clinical oncologists [20]. All the patients gave informed consent to participate in the study. The patients group consists of 29 patients with primary ovarian cancers (cystadenocarcinoma $(n=3)$, endometrioid carcinoma $(\mathrm{n}=6)$, papillary carcinoma $(n=5)$, teratoma $(n=1)$, mesonephroma $(n=1)$, ovarian adenocarcinoma $(n=11)$, undifferentiated carcinoma $(n=2)$ ). Among the ovarian cancer patients 8 have stage I $(27.6 \%)$, 4 - stage II (13.8\%), 16 - stage III (55.2\%) and 1 - stage IV (3.4\%), 16 patients have invasion and metastasis.

The material of our study is the DNA samples obtained from the surgical material of ovarian tumors (cytologically confirmed in not less than $70 \%$ of cancer cells) and conditionally normal surrounding tissues of the OC-patients.

The study of genomic rearrangements in the HLA region was performed using LOH analysis of the STR-markers located in HLA chromosome region: D6S2678 (class I) and D6S2925 (class III). One of the PCR-primers for each STR-marker amplification was labeled by $\mathrm{Cy} 5$ fluorescent dye fabricated by Methabion, Germany. $15 \mu$ of PCR mixture contained 1x FIREPol ${ }^{\circledR}$ Master Mix Ready to Load with $7.5 \mathrm{mM} \mathrm{MgCl} 2$ (Solis BioDyne), $60 \mu \mathrm{mol}$ of primers and $200 \mathrm{ng}$ of gDNA. PCR was carried out on 9200 Thermal Cycler (Applied Biosystems), 35 cycles at $60{ }^{\circ} \mathrm{C}$ an- 
nealing temperature. The fragment analysis of the PCR-amplicons was carried out by electrophoresis in a denaturated polyacrylamide gel on the automatic laser analyzer ALF-express II system. The allele discrimination and allelic imbalance were analyzed using ALFexpress Fragment Manager Software.

\section{Allelic imbalance calculation}

AR (allele ratio): ratio of the intensity of the alleles in a sample:

$\mathrm{AR}=\mathrm{S}_{\text {alele1 }} / \mathrm{S}_{\text {alele2 }} ; \mathrm{S}-$ peak area of the allele.

AI (allelic imbalance): ratio of AR values of normal and tumor samples of the same patient:

$$
\mathrm{AI}=\mathrm{AR}_{\text {normal }} / \mathrm{AR}_{\text {tumor }}
$$

Limits of $\mathrm{LOH}$ value: $0.67>\mathrm{AI}>1.35$.

\section{Results}

Previously, we elaborated the set of 3 STRmarkers inside the HLA-locus and screened the extent, to which they were informative in the DNA samples of healthy individuals. The selected HLA-markers D6S2678 (class I), DQIV (class II) and D6S2925 (class III) had the highest heterozygosity indexes and the largest number of different alleles, data not shown.

According to the basic principle of $\mathrm{LOH}$ analysis in tumor-normal pairs the locus will be informative if the two alleles of the marker in the normal tissue have different lengths

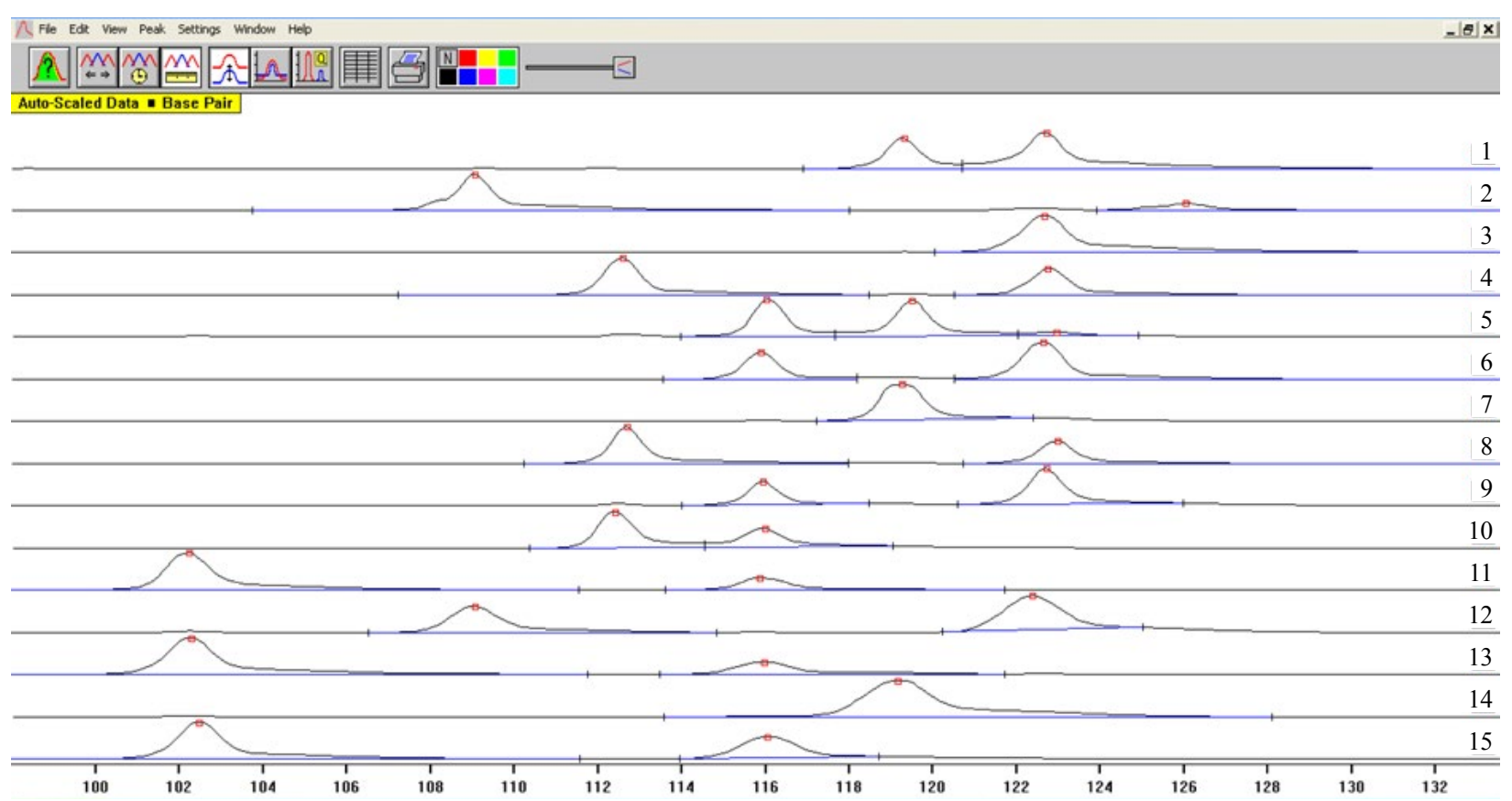

Fig. 1. D6S2925 genotypes in normal samples of OC-patients, ALF-fluorogram of PCR products. Samples in lines 3, 7 and 14 were uninformative by this STR-marker due to homozygous genotypes. 

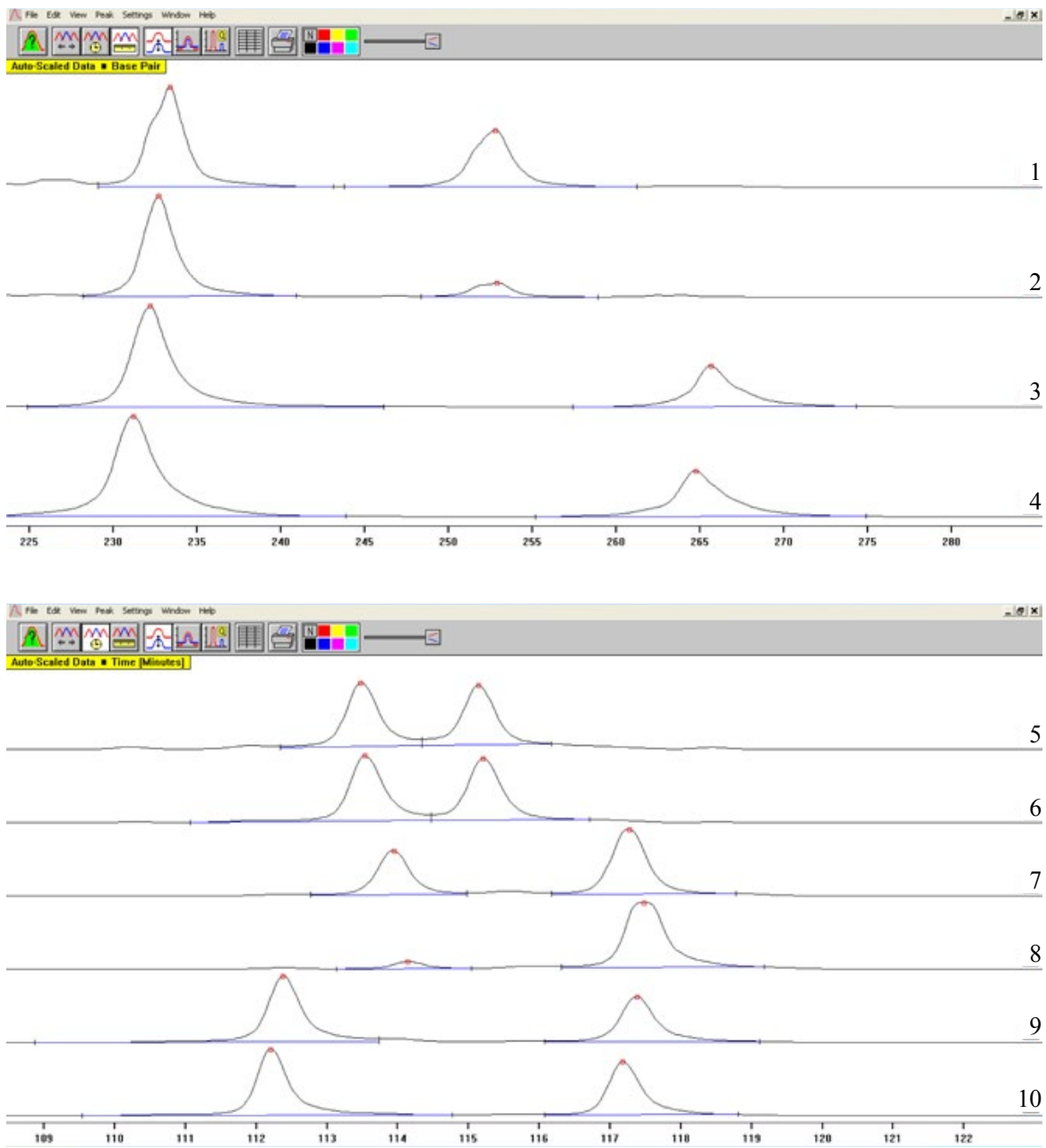

C

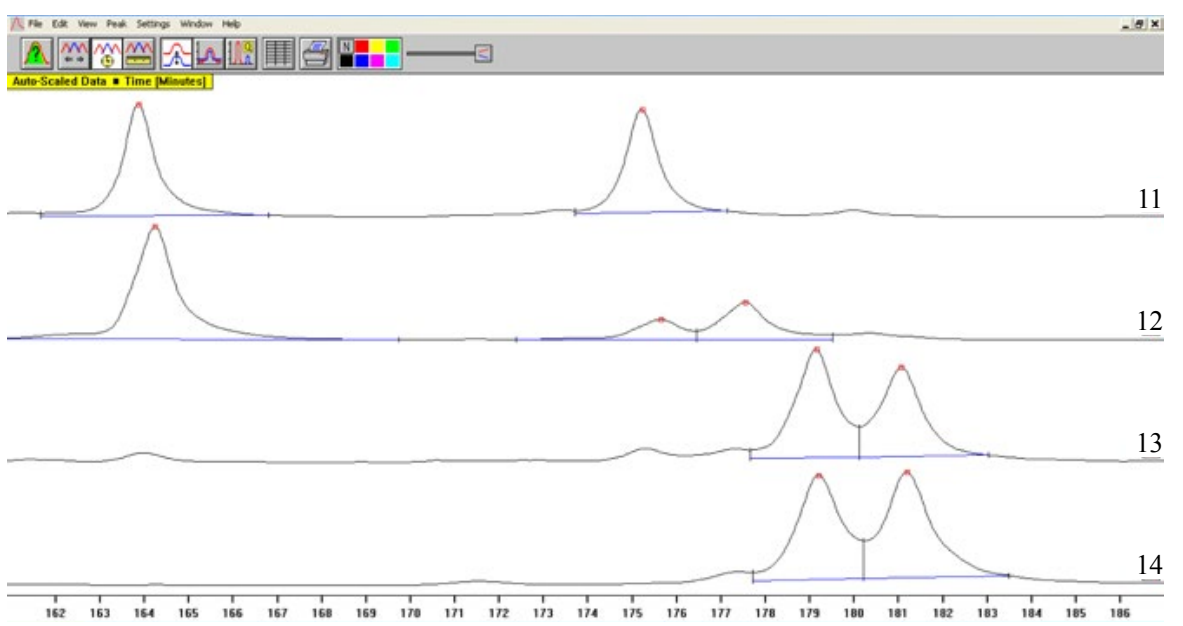

Fig. 2. LOH-analysis of paired samples (tumornormal) in patients with ovarian cancer: $A-$ DQIV (lines 1-4), BD6S2925 (lines 5-10), C-D6S2678 (lines 1114); odd lines - normal tissue samples, even lines - appropriate tumor samples. The patient samples in lines 1-2 demonstrate a partial somatic deletion in the HLA class II region in the tumor tissue, in lines 7-8-partial somatic allele deletion in the HLA class III region in the tumor tissue and in lines 11-12 - partial somatic insertion of 1 tandem repeat in the longer allele of the STR in the tumor tissue. 
(heterozygous genotype). Therefore, we screened all normal samples for the extent they were informative by each STR-marker to determine the normal samples genotypes (Fig. 1).

\section{LOH-analysis of STR-markers in tumor samples from patients with ovarian cancer} We tested 29 DNA samples of normal tissues; the paired tumor sample was analyzed only in case of a normal sample's heterozygous genotype of the STR-marker. One patient appeared to be not informative for $\mathrm{LOH}$-analysis by all three STR-markers (homozygous genotype). Six patients were fully informative by all studied markers (heterozygous genotypes), and the other ones were informative by 2 or 1 markers - 25 normal samples of OC-patients were heterozygous by D6S2678, 23 - by DQIV, and 13 - by D6S2925.

All informative pairs of samples (normal heterozigotes - tumor) of 28 patients passed through the LOH comparative analysis (Fig. 2).

No alterations in the HLA-markers have been observed only in 5 tumors.

There were $40.0 \%$ of the ovarian tumors $(10 / 25)$, in which the somatic alterations were detected in the chromosomal region of the HLA class I - D6S2678: 8 samples with partial allele deletions, 1 tumor with total allele loss and 1 tumor with a mutation in STR allele - somatic insertion of a tandem repeat. The HLA class II (DQIV) somatic reorganizations were found in $46.2 \%$ of the samples of ovarian tumors $(6 / 13)$, all the tumors had partial deletions of the STR allele. In $60.8 \%$ of the studied OC-samples (14/23) somatic reorganizations were identified in the chromosomal region of HLA class III - D6S2925: in 11 patients the tumor samples had partial dele- tions of the STR-allele, 1 tumor had total allele loss, and in 2 tumors the somatic mutations in the STR allele - insertion of tandem repeats - were detected (Fig. 3).

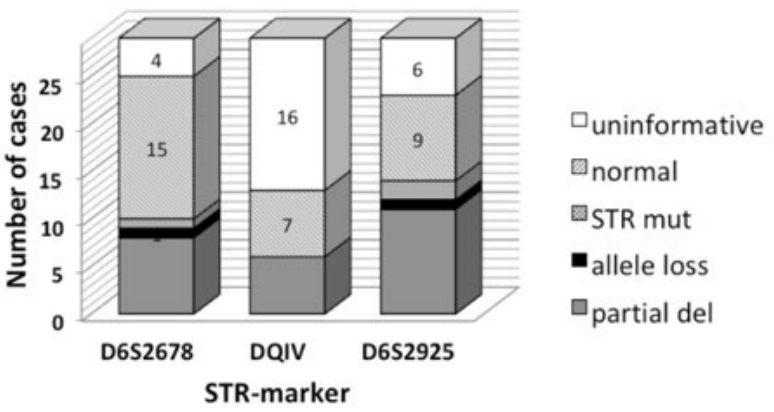

Fig. 3. The spectrum of detected alterations in HLA-locus: uninformative - homozygous genotype of patient's normal tissue; normal - tumors without allelic imbalance and STR-mutations; STR mut - insertion of tandem repeats in the STR allele in a part of tumor cells; allele loss - deletion of the STR allele in more than $99 \%$ of tumor cells, partial del - deletion of the STR allele in more than $35 \%$ of tumor cells $(0.67>\mathrm{AI}>1.35)$.

\section{Patients with alterations in two HLA loci}

Analyzing the patients combined genotypes by the 3 studied markers we noted that in 8 ovarian tumors the somatic changes were detected in more than one locus (Tab. 1).

It is well-known that the HLA class I and II loci are associated with CD4+ and CD8+ T cell activation, used in the majority of the developed cancer immune vaccines. Therefore, they are the most critical for the immunotherapy outcome. We detect the complex alterations in the HLA class I and II loci in one IIIc-stage aggressive papillary carcinoma with metastasis in uterus and omentum in the pa- 
Table 1. Patients with complex alterations in the HLA-locus

\begin{tabular}{|c|c|c|c|c|c|c|c|c|}
\hline ID & ov t3 & ov t15 & ov t5 & ov $t 42$ & ov t23 & ov t27 & ov t21 & ov t20 \\
\hline Age & 49 & 54 & 65 & 52 & 56 & 48 & 50 & 59 \\
\hline TNM & $\mathrm{T}_{3 \mathrm{c}} \mathrm{H}_{0} \mathrm{M}_{0}$ & $\mathrm{~T}_{3 \mathrm{c}} \mathrm{H}_{0} \mathrm{M}_{0}$ & $\mathrm{~T}_{3 \mathrm{c}} \mathrm{H}_{0} \mathrm{M}_{0}$ & $\mathrm{~T}_{3 \mathrm{c}} \mathrm{H}_{0} \mathrm{M}_{1}$ & $\mathrm{~T}_{3 \mathrm{a}} \mathrm{H}_{0} \mathrm{M}_{0}$ & $\mathrm{~T}_{2 \mathrm{c}} \mathrm{H}_{0} \mathrm{M}_{0}$ & $\mathrm{~T}_{3 \mathrm{c}} \mathrm{H}_{0} \mathrm{M}_{0}$ & $\mathrm{~T}_{3 \mathrm{c}} \mathrm{H}_{0} \mathrm{M}_{0}$ \\
\hline Stage & IIIc & IIIc & IIIc & IIIc & IIIa & IIc & IIIc & IIIc \\
\hline Morphology & $\begin{array}{c}\text { Papillary } \\
\text { carcinoma }\end{array}$ & $\begin{array}{l}\text { Adenocar- } \\
\text { cinoma }\end{array}$ & $\begin{array}{l}\text { Adenocar- } \\
\text { cinoma }\end{array}$ & $\begin{array}{c}\text { Papil. } \\
\text { serous } \\
\text { adenocar- } \\
\text { cinoma }\end{array}$ & $\begin{array}{l}\text { Endometr. } \\
\text { carcinoma }\end{array}$ & $\begin{array}{c}\text { Adenocar- } \\
\text { cinoma }\end{array}$ & $\begin{array}{l}\text { Endometr. } \\
\text { carcinoma }\end{array}$ & $\begin{array}{l}\text { Adenocar- } \\
\text { cinoma }\end{array}$ \\
\hline $\begin{array}{l}\text { Differen- } \\
\text { tiation }\end{array}$ & $\mathrm{G} 2$ & G3 & $\mathrm{G} 2$ & G3 & G3 & $\mathrm{G} 2$ & G2 & G3 \\
\hline $\begin{array}{l}\text { Invasion, } \\
\text { metastasis }\end{array}$ & $\begin{array}{c}\text { omentum, } \\
\text { uterus }\end{array}$ & ovary & omentum & $\begin{array}{l}\text { omentum, } \\
\text { peritoneum }\end{array}$ & ovary & - & - & omentum \\
\hline pCT & 7 courses & - & 3 courses & - & - & - & 3 courses & - \\
\hline D6S2678 & $A I=1.6$ & $\mathrm{AI}=0.88$ & $\mathrm{AI}=1.28$ & homo & $\mathrm{AI}=\mathbf{0 . 3 5}$ & $\mathrm{AI}=\mathbf{0 . 0 0 2}$ & $\mathrm{AI}=\mathbf{2 . 1 6}$ & $\mathrm{AI}=0.32$ \\
\hline D6S2925 & homo & $\mathbf{A I}=3.7$ & $\mathrm{AI}=1.38$ & $\mathrm{AI}=\mathbf{0 . 3 6}$ & $\mathrm{AI}=9.2$ & $\mathrm{AI}=0.64$ & $\mathrm{AI}=1.40$ & STR mut \\
\hline DQIV & $\mathrm{AI}=0.48$ & $\mathrm{AI}=1.8$ & $\mathrm{AI}=1.9$ & $\mathrm{AI}=18.4$ & homo & homo & homo & $\mathrm{AI}=0.9$ \\
\hline
\end{tabular}

Age - age of patient at the time of OC-surgery; pCT - palliative chemotherapy; AI — index of allele imbalance, marked bold AI indexes indicate the diagnostic significance of LOH-analysis; STR mut - somatic insertion of tandem repeats in the STR allele in a part of tumor cells.

tient passed through 7 courses of palliative chemotherapy.

According to the published data the cluster of class III HLA-genes is not directly related to the activation of the immune response to pathogens and cancer cells, but it contains the genes of transforming growth factors, complement proteins and cytokines - the active components that regulate the immune system. Three of our patients with IIIc-stage invasive adenocarcinomas and metastasis appeared to have complex HLA somatic deletions in class II and III loci. The other three patients had the tumors with partial deletions in HLA class I and III and one - the tumor with the partial deletion in the HLA class I and the mutation in the HLA III STR allele, located not far from the MICB gene (HLA Class I Polypeptide-Related Sequence B) on the border of classes I and III. These 4 patients have various types of cancer morphology on different stages (IIc, IIIa and IIIc), their tumors are invasive.

\section{Discussion}

Based on the results obtained, it could be assumed that at various stages of ovarian cancer, the complex somatic changes, involving several HLA loci, are quite common. The detected genetic alterations vary by both the type (deletions and STR-mutations) and the proportion between the sub-population of cells with mutations and the general population of tumor cells (from a minor amount at the border of the resolving power of the $\mathrm{LOH}$-technique to complete allele loss). We identified an insertion in STR alleles in tree tumors, which have not been reported previously for ovarian tumors. For comparison, the frequency of such insertions in human germ cells (non-oncological) 
is on average $1 \times 10^{-3}[21]$. Thus, we once again confirm that the frequency of genomic reorganizations is not limited to deletions and amplifications and significantly increases during oncogenesis.

Summarizing our results it could be indicated that the spectrum of genomic mutations in the HLA genomic region consists of partial deletions ( $83.3 \%-25$ of 30 alterations), full allele loss $(6.7 \%)$ and STR tandem repeat insertions $(10.0 \%)$. We also indicate that the HLA genomic rearrangements in individual ovarian tumors may be either complex, affecting at least 2 loci, or isolated, occurring only in one examined locus. It could be hypothesized that the complex deletions in several HLA clusters are the result of an extended deletion, which is not limited to one HLA gene cluster. First of all, this assumption is based on our results, according to which three tumors had deletions of alleles in STR markers localized in neighboring HLA gene clusters: D6S2678 (HLA-E-HLA-C) and D6C2925 (HLA-B - LT cytokine, class III). As far as we know, the ovarian tumors with complex HLA genomic rearrangements involving class III genes in combination with class I or II HLA-regions have not been previously described.

According to our results, the abnormalities in more than one of the markers studied were identified mainly at the latest stages of ovarian cancer, 6 of 8 tumors with two alterations (Tab. 1) were at the stage IIIc. There were no tumors with stage Ia or Ib in this group whereas in our general OC-group there were 8 patients with the stage I tumors $(p=0.02$, Fisher exact test). This corresponds to the well-known facts that at the later stages of the disease, OC tumors have weak response to chemotherapy and metastasize to adjacent organs. It could be assumed that in the process of oncogenesis, the tumor continues to accumulate the alterations in the immune response genes, thereby becoming increasingly aggressive, invasive and metastatic.

In order to study in detail the correlations of isolated and combined reorganizations in HLA loci with the pathogenesis of ovarian cancer and the response to chemo- and immunotherapy, it is necessary to enlarge the panel of markers and increase the patients group. Additionally, we are planning to study the formation of individual immune response to ovarian tumors with genetic damage in HLA loci.

It was demonstrated in many studies that chromosome aneuploidy, deletions and amplifications of a part of the genetic material of different chromosomes were a frequent event in different types of epithelial tumors, including ovarian tumors [22]. The significance of HLA gene expression in an anti-tumour immune response has long been known. Most of the data on the association of HLA and ovarian cancer were based on the analysis of the average expression of HLA genes in OCtumors. In these studies, both increased and decreased expression of genes in the I and II classes had been shown [23-25]. Such contradictions point to the heterogeneity of the expression of HLA antigens in tumors and microenvironment which has] to be clarified. In the era of development of immuno-vaccines for the treatment of cancer, researchers returned to the study of the expression of different types of HLA antigens. It was found that the down regulation of the expression of HLA class I and II antigens was associated with a 
worse prognosis and poor response to therapy of ovarian tumors [24-27]. However, as we have noted above, high genetic and epigenetic heterogeneity within a single tumor, appeared to be the main difficulty in the study of epithelial cancers. The cell-to-cell variability in gene expression does not allow evaluation of the dynamics of the targeted immune treatment without the single cell analysis to be involved for the assessment of minor tumor cell-populations possibly resistant to the vaccine. With the development of tolerance to immunotherapy, the minor genotypes of cancer cells, which avoid immune recognition are really important. That is why for the screening of alterations in the HLA-region we have chosen the approach of LOH-analysis, which allows the detection of even minor reorganizations at the genetic level. Of course, this approach does not directly prove that a part of the tumor cells does not contain certain HLA antigens, but does indicate such a probability. Moreover, the genomic reorganizations in HLA locus were studied in different HLA gene clusters simultaneously and it is much cheaper and faster than single-cell RNA-sequencing. LOHanalysis of HLA STRs made it possible to identify the complex alterations of the HLAregion in ovarian tumors. The foregoing facts allow the application of the algorithm used by us as one of the informative method for rapid screening prior to choosing the treatment tactics and for monitoring the effectiveness of therapy at the early stages.

\section{Conclusions}

Based on the results obtained, we can conclude that the STR-based LOH-analysis allows the detection of aneuploidy and different types of somatic genomic reorganizations in the HLA region even in minor cell populations. It will provide additional prognostic information given that the estimation of the average gene expression level in the tumor tissue might be not accurate when a decrease in the expression of the studied gene in a population of tumor cells is offset by increased expression of the same gene in the other cells of the same tumor. The STR-analysis would be used for routine screening to identify patients at risk of complications in ovarian cancer immunotherapy and for choosing a personalized approach to immunotherapy, since damage in HLA-antigens of different classes may be associated with a resistance to the targets of immunotherapy (CD8+ or CD4+ $\mathrm{T}$ cells inducing pathways).

\section{Acknowledgements}

The authors would like to thank the clinical oncologists from Kiev oncological hospital for their participation in the survey of patients and support providing patients' samples and clinical information. We are also grateful to the patients for their kind consent to participate in the study.

\section{Funding}

This work was supported by the National Academy of Sciences of Ukraine (grant \#7B, 2017-2018).

\section{Conflict of Interest}

The authors declare that they have no conflict of interest

Statement of compliance with standards of research involving humans as subjects. All procedures carried out in the studies in- 
volving people were consistent with international and national standards, the Helsinki Declaration of 1964, and its later amendments, and approved by the Bioethics Commission of the Institute of Molecular Biology and Genetics, National Academy of Sciences of Ukraine (26.01.2021, report No.1).

\section{REFERENCES}

1. Suh DH, Kim M, Lee KH, Eom KY, Kjeldsen $M K$, Mirza MR, Kim JW. Major clinical research advances in gynecologic cancer in 2017. J Gynecol Oncol. 2018;29(2):e31.

2. Liu XS, Mardis ER. Applications of Immunogenomics to Cancer. Cell. 2017;168(4):600-612.

3. Flores-Villanueva PO, Ganachari $M$, Guio $\mathrm{H}$, Mejia JA, Granados $J$. An Isolated TCR $\alpha \beta$ Restricted by HLA-A*02:01/CT37 Peptide Redirecting CD8+ T Cells To Kill and Secrete IFN- $\gamma$ in Response to Lung Adenocarcinoma Cell Lines. J Immunol. 2018;200(8):2965-2977.

4. Ovarian Tumor Tissue Analysis (OTTA) Consortium, Goode EL, Block MS, Kalli KR, Vierkant RA, Chen $W$, Fogarty ZC, Gentry-Maharaj $A$, Toloczko A, Hein A, Bouligny AL, Jensen A, Osorio A, Hartkopf A, Ryan A, Chudecka-Gtaz A, Magliocco AM, Hartmann A, Jung AY, Gao B, Hernandez BY, Fridley BL, McCauley BM, Kennedy CJ, Wang $C$, Karpinskyj $C$, de Sousa $C B$, Tiezzi DG, Wachter DL, Herpel E, Taran FA, Modugno F, Nelson G, Lubiński J, Menkiszak J, Alsop J, Lester J, Garcia-Donas J, Nation J, Hung J, Palacios J, Rothstein JH, Kelley JL, de Andrade JM, Robles-Díaz L, Intermaggio MP, Widschwendter $M$, Beckmann MW, Ruebner $M$, Jimenez-Linan $M$, Singh $N$, Oszurek O, Harnett PR, Rambau PF, Sinn P, Wagner P, Ghatage P, Sharma R, Edwards RP, Ness RB, Orsulic S, Brucker SY, Johnatty SE, Longacre TA, Ursula E, McGuire V, Sieh W, Natanzon Y, Li Z, Whittemore AS, Anna A, Staebler A, Karlan BY, Gilks B, Bowtell DD, Høgdall E, Candido dos Reis FJ, Steed H, Campbell IG, Gronwald J, Benitez J, Koziak JM,
Chang-Claude J, Moysich KB, Kelemen LE, Cook LS, Goodman MT, García MJ, Fasching PA, Kommoss S, Deen S, Kjaer SK, Menon U, Brenton JD, Pharoah PDP, Chenevix-Trench G, Huntsman DG, Winham SJ, Köbel M, Ramus SJ. DoseResponse Association of CD8+ Tumor-Infiltrating Lymphocytes and Survival Time in High-Grade Serous Ovarian Cancer. JAMA Oncol. 2017; 3(12): 173290.

5. Santoiemma PP, Powell DJ Jr. Tumor infiltrating lymphocytes in ovarian cancer. Cancer Biol Ther. 2015;16(6):807-20.

6. Abelin JG, Harjanto D, Malloy M, Suri P, Colson T, Goulding SP, Creech AL, Serrano LR, Nasir G, Nasrullah Y, McGann CD, Velez D, Ting YS, Poran $A$, Rothenberg DA, Chhangawala $S$, Rubinsteyn A, Hammerbacher J, Gaynor RB, Fritsch EF, GreshockJ, Oslund RC, Barthelme D, Addona TA, Arieta CM, Rooney MS. Defining HLA-II Ligand Processing and Binding Rules with Mass Spectrometry Enhances Cancer Epitope Prediction. Immunity. 2019;51(4):766-779.e17.

7. Smith $H A$, Rekoske BT, McNeel DG. DNA vaccines encoding altered peptide ligands for SSX2 enhance epitope-specific CD8+ T-cell immune responses. Vaccine. 2014;32(15):1707-15.

8. Boettcher AN, Usman A, Morgans A, VanderWeele DJ, Sosman J, Wu JD. Past, Current, and Future of Immunotherapies for Prostate Cancer. Front Oncol. 2019;9:884.

9. Gálvez-Cancino F, López E, Menares E, Díaz X, Flores $C$, Cáceres P, Hidalgo S, Chovar O, Alcántara-Hernández M, Borgna V, Varas-Godoy $M$, Salazar-Onfray F, Idoyaga J, Lladser A. Vaccination-induced skin-resident memory CD8+ T cells mediate strong protection against cutaneous melanoma. Oncoimmunology. 2018;7(7):e1442163.

10. Neumann A, Hörzer H, Hillen N, Klingel K, SchmidHorch B, Bühring HJ, Rammensee HG, Aebert H, Stevanović $S$. Identification of HLA ligands and T-cell epitopes for immunotherapy of lung cancer. Cancer Immunol Immunother. 2013;62(9):1485-97.

11. Seliger B, Stoehr R, Handke D, Mueller A, Ferrone $S$, Wullich B, Tannapfel A, Hofstaedter F, Hartmann A. Association of HLA class I antigen abnor- 
malities with disease progression and early recurrence in prostate cancer. Cancer Immunol Immunother. 2010;59(4):529-40.

12. Ottenhof SR, Djajadiningrat $R S$, Thygesen $H H$, Jakobs PJ, Jóźwiak K, Heeren AM, de Jong J, Sanders J, Horenblas S, Jordanova ES. The Prognostic Value of Immune Factors in the Tumor Microenvironment of Penile Squamous Cell Carcinoma. Front Immunol. 2018;9:1253.

13. Bosch JJ, Thompson JA, Srivastava MK, Iheagwara UK, Murray TG, Lotem M, Ksander BR, Ostrand-Rosenberg $S$. MHC class II-transduced tumor cells originating in the immune-privileged eye prime and boost CD4(+) $\mathrm{T}$ lymphocytes that cross-react with primary and metastatic uveal melanoma cells. Cancer Res. 2007;67(9):4499-506.

14. Garrido F. HLA Class-II Expression in Human Tumors. Adv Exp Med Biol. 2019;1151:91-95.

15. Accolla RS, Ramia E, Tedeschi A, Forlani G. CIITADriven MHC Class II Expressing Tumor Cells as Antigen Presenting Cell Performers: Toward the Construction of an Optimal Anti-tumor Vaccine. Front Immunol. 2019;10:1806.

16. Doonan BP, Haque A. Prostate Cancer Immunotherapy: Exploiting the HLA Class II Pathway in Vaccine Design. J Clin Cell Immunol. 2015;6(4):351.

17. Dalerba P, Kalisky T, Sahoo D, Rajendran PS, Rothenberg ME, Leyrat AA, Sim S, Okamoto J, Johnston DM, Qian D, Zabala M, Bueno J, Neff NF, Wang J, Shelton AA, Visser B, Hisamori S, Shimono $Y$, van de Wetering $M$, Clevers $H$, Clarke MF, Quake SR. Single-cell dissection of transcriptional heterogeneity in human colon tumors. Nat Biotechnol. 2011;29(12):1120-7.

18. Lee MC, Lopez-Diaz FJ, Khan SY, Tariq MA, Dayn Y, Vaske CJ, Radenbaugh AJ, Kim HJ, Emerson BM, Pourmand N. Single-cell analyses of transcriptional heterogeneity during drug tolerance transition in cancer cells by RNA sequencing. Proc Natl Acad Sci U S A. 2014;111(44):E4726-35.

19. Ding $S$, Chen $X$, Shen $K$. Single-cell RNA sequencing in breast cancer: Understanding tumor heterogeneity and paving roads to individualized therapy. Cancer Commun (Lond). 2020;40(8):329-344.
20. Gordiyuk VV, Gerashchenko GV, Skrypkina IYa, Symonchuk OV, Pavlova TV, Ugryn DD, Manzhura EP, Vakulenko GO, Zabarovsky ER, Rynditch AV, Kashuba VI. Identification of chromosome 3 epigenetic and genetic abnormalities and gene expression changes in ovarian cancer. Biopolym Cell. 2008; 24(4):323-32.

21. Aşicioglu F, Oguz-Savran F, Ozbek U. Mutation rate at commonly used forensic STR loci: paternity testing experience. Dis Markers. 2004;20(6):313-5.

22. Kübler K, Arndt PF, Wardelmann E, Landwehr C, Krebs D, Kuhn W, van der Ven $K$. Genetic alterations of HLA-class II in ovarian cancer. Int $J$ Cancer. 2008;123(6):1350-6.

23. Schuster H, Peper JK, Bösmüller HC, Röhle K, Backert L, Bilich T, Ney B, Löffler MW, Kowalewski DJ, Trautwein N, Rabsteyn A, Engler T, Braun S, Haen SP, Walz JS, Schmid-Horch B, Brucker SY, Wallwiener D, Kohlbacher O, Fend F, Rammensee HG, Stevanović $S$, Staebler A, Wagner P. The immunopeptidomic landscape of ovarian carcinomas. Proc Natl Acad Sci U S A. 2017;114(46):E9942-E9951.

24. Andersson E, Poschke I, Villabona L, Carlson JW, Lundqvist A, Kiessling R, Seliger B, Masucci $G V$. Non-classical HLA-class I expression in serous ovarian carcinoma: Correlation with the HLA-genotype, tumor infiltrating immune cells and prognosis. Oncoimmunology. 2015;5(1):e1052213.

25. Hirohashi Y, Torigoe T, Mariya T, Kochin V, Saito T, Sato N. HLA class I as a predictor of clinical prognosis and CTL infiltration as a predictor of chemosensitivity in ovarian cancer. Oncoimmunology. 2015;4(5):e1005507.

26. Pellicciotta I, Yang CP, Goldberg GL, Shahabi S. Epothilone B enhances Class I HLA and HLA-A2 surface molecule expression in ovarian cancer cells. Gynecol Oncol. 2011;122(3):625-31.

27. Szender JB, Eng KH, Matsuzaki J, Miliotto A, Gnjatic $S$, Tsuji $T$, Odunsi $K$. HLA superfamily assignment is a predictor of immune response to cancer testis antigens and survival in ovarian cancer. $G y$ necol Oncol. 2016;142(1):158-162. 


\section{Соматичні геномні реорганізації ділянки лейкоцитарних антигенів людини в солідних пухлинах ясчників}

Н. В. Грищенко, В. В. Гордіюк, С. А. Кравченко, С. Б. Арбузова, В. І. Кашуба

Успіх імунотерапії раку яєчників визначається ефективністю імунної відповіді пацієнта, а також якісною і кількісною представленістю антигенів основного комплексу гістосумісності в пухлинних клітинах і мікрооточенні. Рівень експресії генів HLA (лейкоцитарних антигенів людини) в пухлинній тканині не завжди коректно відображає експресію цих генів в різних популяціях пухлинних клітин. Мета. Аналіз частоти і спектру соматичних делеций і дуплікацій в локусі HLA. Методи. LOH-аналіз (втрата гетерозиготності) STR-маркерів (короткі тандемні повтори) в пухлинах яєчників пацієнтів. Результати. Ми показали, що складні соматичні геномні реорганізації, в яких залучені кілька локусів HLA, досить часто зустрічаються в пухлинах яєчників. Виявлені генетичні зміни розрізняються як по типу (делеції і мутації в аллелях STR), так і за кількістю субпопуляцій клітин з мутаціями. Висновки. Отримані результати дозволяють запропонувати LOH-аналіз як ефективний метод для виявлення анеуплоїдії та інших типів соматичних геномних реорганізацій у ділянці HLA навіть в мінорних популяціях клітин. Цей аналіз надає додаткову прогностичну інформацію для визначення ефективності різних типів імунотерапії раку яєчників на індивідуальному рівні.

К л ю ч о в і с л о в а: рак яєчників, імунна відповідь, STR-маркер, HLA, генетичні зміни.

\section{Соматические геномные реорганизаци региона лейкоцитарных антигенов человека в солидных опухолях яичников}

Н. В. Грищенко, В. В. Гордиюк, С. А. Кравченко, С. Б. Арбузова, В. И. Кашуба

Успех иммунотерапии рака яичников определяется эффективностью иммунного ответа пациента, а также качественной и количественной представленностью антигенов основного комплекса гистосовместимости в опухолевых клетках и микроокружении. Уровень экспрессии генов HLA (лейкоцитарных антигенов человека) в опухолевой ткани не всегда корректно отражает экспрессию этих генов в различных популяциях опухолевых клеток. Цель. Анализ частоты и спектра соматических делеций и дупликаций в локусе HLA. Методы. LOH-анализ (потеря гетерозиготности) STR-маркеров (короткие тандемные повторы) в опухолях яичников пациентов. Результаты. Мы показали, что сложные соматические геномные реорганизации, затрагивающие несколько локусов HLA, довольно часто встречаются при опухолях яичников. Выводы. Обнаруженные генетические изменения различаются как по типу (делеции и мутации в аллелях STR), так и по количеству субпопуляции клеток с мутациями. Полученные результаты позволяют предложить LOHанализ в качестве эфективного метода для выявления анеуплоидии и других типов соматических реорганизаций генома в регионе HLA даже в минорных популяциях клеток. Этот анализ предоставляет дополнительную прогностическую информацию для определения эффективности различных типов иммунотерапии рака яичников на индивидуальном уровне.

Кл ю ч в в е с л о в а: рак яичников, иммунный ответ, STR-маркер, HLA, генетические изменения.

Received 20.10.2020 